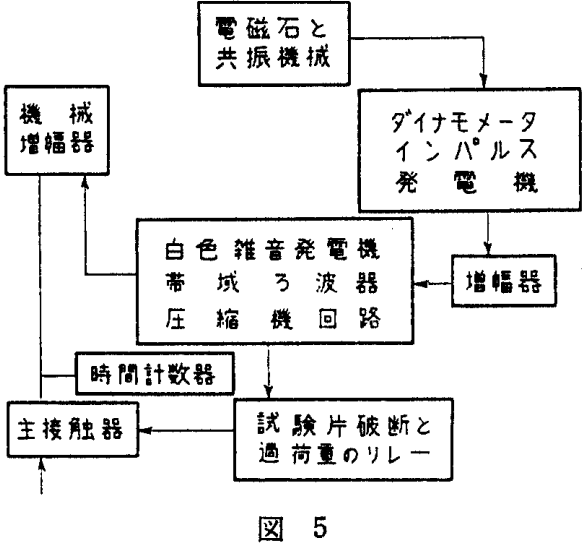

少なくとも $r m s$ 值の 4 倍まではレーリー分布にした がう. また，定振幅の正弦波荷重においては，試験機 はランダム荷重においいて生ずるような平均応力を加え られる能力がある.

[小林 英男]

539.43.01 : 539.388 .1

[57]程々なる材料の刃状き裂を進展させるのに必 要な雬返し応力におよほす引張平均応力の影望 [N. E. Frost and A.F. Greenan, J. Mech. Engng. Sci., 1970, Vol. 12, No. 3, p. 159 168, 図 6, 表 6] 平均応力を $\sigma_{m}$, 応力振幅を $\sigma_{a}$ としたとき, $\sigma_{m} \geqq \sigma_{a}$, $\sigma_{m}+\sigma_{a}<$ 降伏応力のもとで $\sigma_{m} \pm \sigma_{a}$ の応力繰返しを 受ける 12 種類の金属材料の板状試験片における長さ $l$ なる刃状き裂が進展を開始するか否かの条件が実験 的に調べられている. $\sigma_{m}=0$ の両振りの場合にはその ような条件を決定するところのパラメータは $\sigma_{a}^{3} l$ であ ったが，同様に $\sigma_{a}^{3} l>c_{m}$ ならばき裂は進展を開始し， $\sigma_{a}^{3} l<c_{m}$ ならばき裂は進展を開始しない. $c_{m}$ は材料 と $\sigma_{m} / \sigma_{a}$ の值に依存する定数である. ある $\sigma_{m} / \sigma_{a}$ の 值以上で， $c_{m}$ は材料によって異なる最小の值に達す る. この最小值は 1 回の応力繰返しでき裂は少なくと む1原子間隔以上進展すると仮定して著者らのき裂進 展速度の式から導かれる值に一致している。なお，著 者らの実験結果は前に報告された軟鎆の結果(1)をも含 めて，実験的にも $c_{m}$ と $\sigma_{m} / \sigma_{a}$ の量的な関係は明ら かにされていない，摘録者らは $c_{m}$ と $\sigma_{m} / \sigma_{a}$ との関 俰を炭素鋼についてすでに理諭的に明らかにしている が(2)，その理論はここでの種々なる金属材料の実験結 果にも適用できる(3).

(1) Frost, N.E. and Greenan, A.F., J. Mech. Engng. Sci., 9-3 (1967), 234.

（2）小林・中沢，機腈䑳，No. 700-2 (昭 45-4)，175.

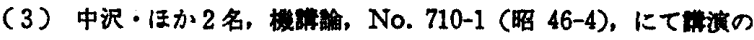
予定.

\section{[小林 英男]}

\subsubsection{1 : $\mathbf{5 3 9} .388 .1: 625.143$}

\section{※[58]レール鋼の疲れき裂進展と䔡激な緅終破坮}

[P.R.V. Evans, N.B. Owen, and B.E. Hopkins, $J$. Iron and Steel Inst., 1970-6, Vol. 208, Pt. 6, p. $560 \sim 567$, 図 12, 表 2] 鉄道のレールのウェブか ら $0^{\circ}$ (長手)， $45^{\circ}$ および $90^{\circ}$ (横) 方向に採取した 鋼について，中央に切久きを有する板状試験片を用い る片振り引張りの疲れ試験が行なわれ，疲れき裂進展 速度と最終的な一方向破壊が生ずるときのき裂長さが 調ベられている. 疲れき裂進展速度 $d l / d N$ は応力应
大俰数の範囲 $\Delta K$ をもって良く表示され，その関係は Paris らと同様に次式のようになる。 $d l / d N=0.87 \times 10^{-23}(\Delta K)^{4}$

ここでき裂長さ $l$ は in, $\Delta K$ は $\mathrm{lbf} \mathrm{in-3/2} \mathrm{である.}$ ただし l の小さい範囲においては $d l / d N$ は $l$ に比例 しており，Frost らの結果と同様である．また，最終 的な一方向破㙉の生ずる少し前から $d l / d N$ は $\Delta K$ と の関係からはずれて大きくなって行く．最終的な一方 向破壊が生ずる限界のき裂長さ $l_{c}$ は試験片の採取方 向に無関係に次式で与えられる.

$$
1-2 l_{c} / W=1.3 \times 10^{-5} \sigma_{\max }
$$

ここで試験片の幅 $W$ は in, 最大負荷応力 $\sigma_{\max }$ は lbf in $^{-2}$ である.これらの二つの式を組合わせること により，あらかじめ波れき裂が存在する試験片の $S-N$ 関係を予知することができる. なお，破面のフラクト グラフィ観察によれば，疲れ破面には条こん（striation), その終わりには厚さ方向の中央に詐立した小さ なへき開の篮所が認められ，最終的な一方向破面には へき開と river マークのみで dimpleのような局部的 な塑性変形の跡は認められず，巨視的な測定結果と対 応している。

[小林 英男]

539.43.01 : 539.388.1 : 669.7

[59] Al 合金におけるへき開面に沿った疲れき裂の 進展 [K.R.L. Thompson and J.V. Craig, Metallur. gical Trans., 1970-4, Vol. 1, No. 4, p. 1047 1049, 図 5] いわゆるぜい性疲れ条こん（brittle fatigue striation）はAl 合金や他の材料について観塞されて おり，(a) 腐食性環境，(b) 低緗返し速度および (c) 低 忘力搪大係数がその形成の条件だとされている. Forsyth によれば，高力 Al 合金のぜい性条こんはへ き開破壤が塑性変形によって阻止された跡である。こ れに対して Laird は，Forsythの観察したき裂進展 面が（100）であり，通常の fcc 金属におけるへき開 面（111）ではないことに疑問を抱き，擬へき開が生 じたのだと考えている. 著者らが実際の使用中に疲れ 破壊した Al 合金 2219-T 6 の航空機のプロペラブレ ードを電子顥微鏡およびX 線で観察したところ, Forsyth のいうように疲れき裂はへき開面に沿って river マークをともないながら不連綍的に進展してい た.しかしながら，へき開面は (100)ではなくて (111) 面に $5^{\circ}$ 以内である.このようなぜい性条こん が観察されるのはき裂長さが小さい籍囲であり，上記 の(c)の条件を満足している. き裂長さが大きくなれば 応力扩大係数も高くなり，延性疲れ条こん（ductile fatigue striation)をともなうような破罢が生ずる.

[小林 英男]

$539.43 .01: 539.388 .1: 678.073$

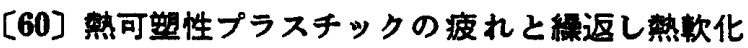

[I. Constable, J.G. Williams, and D.J. Burns, $J$. Mech. Engng. Sci., 1970, Vol. 12, No. 1, p. 20 29, 図 13, 表 1]繰返し荷重を受ける熱可塑性プラ スチックは局部的な温度上界でゆがむか，あるいは使 用状態や製造過程で形成された㸡視き裂ないしは欠陥 からの徐々に増加して行くような（疲れ）き裂の進展 により破壊する.ここでは繰返し熱軟化と称される前 者の形式の破損が，損失コンプライアンス，試験片の 幾何学的形状, および繰返し荷重の速度と大きさと定 